\title{
THE GEOGRAPHIC SCOPE OF THE SVALBARD TREATY AND NORWEGIAN SOVEREIGNTY: HISTORIC - OR EVOLUTIONARY - INTERPRETATION?
}

\author{
Peter Thomas Örebech*
}

\begin{abstract}
Summary: The Svalbard Treaty and its claimed 'extended-reach' jurisdiction incorporating both the continental shelf and exclusive economic zone (EEZ) - ie a fisheries protection zone (FPZ) - is an international law puzzle. Disputes regarding the Treaty's jurisdictione ratione terrae results from interpretative differences. My findings are as follows: the Treaty's concept of 'full and absolute sovereignty' refers to the one-time jurisdiction transfer that occurred in April 1925.

The notion of 'territorial waters' attracts both an historic (static) and evolutionary (dynamic) reading. Regarding its material content, we are faced with the first category. Considering geographic reach, evolutionary reading takes over. 'Territorial water' jurisdictione ratione terrae is a generic form whose reach, which is at most 12 nautical miles, is dynamic. The treaty does not prevent Norway from unilaterally deciding whether to enforce this maximum, or a less extensive, area.
\end{abstract}

While territorial sea jurisdiction due to the development of international law may extend to 12 nautical miles, it cannot creep to 200 nautical miles. Due to substantial variations, the EEZ cannot qualify as a similar zone adjoining the territorial sea.

Further; it is difficult to argue that its reach should include areas beyond the territorial sea of Svalbard due to the very fact that its reach is limited to the 'Svalbard Box'. Coastal state jurisdiction beyond the Box is not granted in the Svalbard Treaty but results from the 1982 Law of the Sea Convention (LOSC).

\section{1 'Travail préparatoire', interpretation and positions: a general approach}

'To a student to modern politics it will appear that ... the actual sovereign is, given time, almost certain to become the legal.'

Sir Geoffrey Butler ${ }^{1}$

This article examines two key juridical facts: 'full and absolute sovereignty' (article 1) and 'territorial waters' (article 2) as expressed in the

\footnotetext{
Professor of Jurisprudence, UIT Arctic University of Norway, Tromsö.

1 Geoffrey Butler, 'Sovereignty and the League of Nations' in The British Year Book of International Law (Henry Frowde and Hodder and Stoughton 1920-21) 35.
} 
1920 Svalbard Treaty. Are these of an evolutionary kind to be interpreted according to the 'inter-temporal law' principle (parts 1.3 and 2.4-2.5)? As revealed, the Treaty does not require one solution suitable for all the Treaty's notions. Each text subscribes to a solution of its own.

\subsection{Introductory remarks}

The Svalbard Treaty serves both as a legal platform for Norway's sovereignty over the archipelago and also bestows limitations on its jurisdiction. Norway thus possesses residual rights (part 1.4).

While Svalbard is indeed a part of the Kingdom of Norway, as set forth in the 1920 Treaty, the Svalbard legal system is in its complexity an 'intricate nuisance'. ${ }^{2}$ Clashing treaty interpretations have caused 'nascent tensions'. ${ }^{3}$ The Treaty raises 'fundamental and abiding issues', ${ }^{4}$ to the list of which, I argue, belongs the puzzle of the possible application of the Treaty to marine areas beyond Svalbard territorial waters, ie whether treaty-based equal rights to mining, fishing and other natural resource extraction relates to the continental shelf and the Fisheries Protection Zone (FPZ).

The key issue is how the Treaty, covering 'all the islands ... in their territorial waters' (article 1) situated between $74^{\circ} \mathrm{N}-81^{\circ} \mathrm{N} \& 10^{\circ} \mathrm{E}-35^{\circ} \mathrm{E}$ (the 'Svalbard Box') ${ }^{5}$ justifies treaty-based jurisdiction beyond the territorial sea. The 'jurisdictione ratione terrae ${ }^{6}$ long-reach proponents' maintain that the FPZ is under Svalbard jurisdiction due either to logical ${ }^{7}$ or natural application ${ }^{8}$ and include the continental shelf in their claim. I seek to clarify this position at its core.

This concept should not be mixed up with 'extraterritorial jurisdiction', which refers to internal law competences vis-à-vis own subjects

\footnotetext{
2 A rather common position in 1920. See RN Rudmose Brown, Spitsbergen. An Account of Exploration, Hunting, the Mineral Riches \& Future Potential of an Arctic Archipelago (London Seeley Service \& Co, Ltd 1920) 299.

3 Diana Wallis 'Introduction' (2011) 1 Arctic papers - The Spitsbergen Treaty. Multilateral Governance in the Arctic' 6.

4 RY Jennings, Book Review: 'International Law, The Collected Papers of Hersch Lauterpacht, vols I \& II' (1976) 13 Cambridge Law Journal 165.

5 Treaty between Norway, the United States of America, Denmark, France, Italy, Japan, the Netherlands, Great Britain and Ireland and Sweden ['the signatories'] relating to Spitsbergen of 9 February 1920. This delimitation was identical to the Norwegian position prior to the Peace conference discussions. See Exposé des Questions Soumises à la Conférence de la Paix par le Ministre de Norvège à Paris au Nom du Gouvernement Norvégien (Paris, 10 April 1919) 2.

$6 \quad$ See esp Wallis (n 3). See also authors referred to in nn 7 and 8.

7 DH Anderson, 'The Status Under International Law of the Maritime Areas around Svalbard' (2009) 40(4) Ocean Development and International Law 373, 374, 380.

8 Geir Ulfstein, The Svalbard Treaty: From Terra Nullius to Norwegian Sovereignty (Scandinavian University Press 1996) 125, 127, 140, 366, 411, 424, 429, 479.
} 
situated beyond the territory of the directing state. Neither should it be confused with 'extraterritoriality' which signifies the position of being exempted from domicile jurisdiction, even if situated on that state's territory, usually resulting from diplomatic negotiations. ${ }^{9}$

This is no historical or political study. ${ }^{10}$ The Svalbard delimitation towards the high seas, deep ocean bed or adjacent states ${ }^{11}$ is also beyond the scope of this article.

This study skips the material issues related to Svalbard harvesting rights (cf the French position which holds that 'the citizens of all the Signatories will have the same fishing and hunting rights in the territory of the archipelago and in its territorial waters' ${ }^{12}$ No parties seem to deny the existence of non-discriminatory harvesting rights to Member States citizens, an undisputed position which will not be subject to further analysis here.

But how to resolve the Svalbard Treaty puzzles? Opinions vary. Whether Norway is a mutatis mutandis trusteeship or mandate was discussed previous to the 1920 Treaty (part 1.2) but has also emerged more recently. ${ }^{13}$

Most jurists reject the terra nullius description of Svalbard, ie a 'territory belonging to no one'. ${ }^{14}$ The core characteristic of such an area is the lack of public possession and jurisdiction. A terra nullius regime consists of both a terra nullius area as well as terra nullius rights. Hence, the rules

9 See as an illustration Philip R Abbey, 'Treaty Ports \& Extraterritoriality in 1920s China. General Discussion and Table of Contents' (1997) (user-generated website) <www.oocities. org/treatyport01/TREATY01.html $\geq$ accessed 25 October 2016.

10 For a comprehensive analysis, see Christopher R Rossi, “A Unique International Problem": The Svalbard Treaty, Equal Enjoyment, and Terra Nullius: Lessons of Territorial Temptation from History' (2015) 15 Washington University Global Studies Law Review 93, with further references.

11 See Commission on the Limits of the Continental Shelf (CLCS). Outer limits of the continental shelf beyond 200 nautical miles from the baselines: Submissions to the Commission: Submission by the Kingdom of Norway ANNEX VI, United Nations Convention on the Law of the Sea Commission on the Limits of the Continental Shelf. Summary of the recommendations of the commission on the limits of the continental shelf in regard to the submission made by Norway in respect of areas in the Arctic Ocean, the Barents Sea and the Norwegian Sea on 27 November 2006. Recommendations prepared by the Subcommission established for the consideration of the submission made by Norway. Adopted by the Subcommission on 13 March 2009, and submitted to the Commission on the Limits of the Continental Shelf for consideration and approval by the Commission. Adopted by the Commission on 27 March 2009, with amendments. See also, the bilateral agreement of 15 September 2010 between Norway and Russia on the marine delimitation and cooperation in the Barents Sea and Polar Sea.

12 Chambre des Députés, Session de 1924, 'Rapport fait au nom de la Commission des Affaires Etrangères. Chargée d'examiner le Projet de Loi Portant approbation de traité relative au Spitzberg, signé à Paris le 9 février 1920' 16. Citation taken from the Archive of the Norwegian Ministry of Foreign Affairs (UD jnr 20970/1924) in the Norway National Archive, Box JD, Dc-0084.

13 As told, for example, by Wallis (n 3).

14 Legal Status of Eastern Greenland (Den v Nor) (1933) PCIJ (Series A/B) No 53, 63. See also the Western Sahara case (1975) ICJ 12, 38-39. 
of domicile governing terra nullius located individuals. Clearly, Svalbard is not terra nullius and I thus refrain from commenting further on the issue.

\subsection{Background incidents leading up to the 1920 Svalbard Treaty}

The WWI negotiations between Norway and Great Britain, Sweden and the Netherlands on Norway's role in holding a mandate failed and never again gained momentum. ${ }^{15}$ Generally, the participants believed that Norway was the right country to trust, but only as a country holding a mandate assigned by the League of Nations. All that said, this never became the outcome. Here is why.

Versailles rejected the mandate bid. During WWI, Norway changed its mind. In 1919, by 'ingenious diplomacy', Norway succeeded 'in accomplishing the ancient Norwegian claim on sovereignty over the archipelago'. ${ }^{16}$ France and the USA, through US Secretary of State, Robert Lansing, ${ }^{17}$ championed the Norwegian stance. ${ }^{18}$ The Spitsbergen Commission 'decided ...unanimously, against which decision the powers most directly concerned made no objection. Soviet objections were forthcoming later'. ${ }^{19}$ The Spitsbergen Supreme Council adopted the Commission recommendation on 25 September 1919. Thus, sovereignty was the choice.

This begs the question regarding the deadlock on the limited Norwegian jurisdiction beyond the territorial waters: being one among many coastal states, what is so special about Norway and its right to adjoining zones of exclusive self-rule (part 2)?

At the time of the Svalbard Treaty proposal (1919), its signing (1920), and its ratification (1925), its 'geographic scope' was a done deal, simply due to the fact that the Treaty's limitations were fixed to areas within the specific longitude and latitude explicitly mentioned in the treaty text $\left(74^{\circ} \mathrm{N}-81^{\circ} \mathrm{N} \& 10^{\circ} \mathrm{E}-35^{\circ} \mathrm{E}\right)$. This is and was a clear-cut definition, giving

15 Trygve Mathisen, Svalbard i internasjonal politikk [Svalbard in International Politics] 1871-1925 (Aschehoug 1951) 201, 202, and esp. 209 (translations from Norwegian documents and literature are by the author of this piece, here as well as in the following texts).

16 Riksarkivet [Norway, National Archive] Utenriksdepartementet [Ministry of Foreign Affairs] Boks 6166A, P1 Brev 12 april 1919, fra legasjonen i Berlin til Utenriksministeren i Kristiania [Letter from the Norwegian Embassy in Berlin to the Minister of Foreign Affairs in the Norwegian Capital of Kristiania (since 1924 given its ancient name Oslo)], ' ... at det maatte lykkes et behändig diplomati at faa gjennemdrevet Norges gamle krav paa overhøihet over Øgruppen'.

17 At first Lansing promoted a system of international governance. See Mathisen (n 15) 180 .

18 Elen C Singh, The Spitsbergen (Svalbard) Question: United States Foreign Policy, 19071935 (Universitetsforlaget 1980). Willy Østreng, Økonomi og politisk suverenitet. Interessespillet om Svalbards politiske status (Universitetsforlaget 1974) [Economy and Political Sovereignty, Power Politics of the Svalbard Political Status] 42-44. The author claims that Norway gained from US policy to prevent too expansive British power after WWI.

19 See Singh (n 18) 103 with further references to the primary sources. 
no leeway to discretionary power. Obviously, this notion of longitude positions has no evolutionary components. No one - not even the most patriotic Norwegians - would allege that the 1920 Treaty included not only the islands within the Svalbard Box but also territories beyond the box.

Nor did the Russians. This was made clear shortly after the Norwegians achieved sovereignty over the archipelago. With regard to the adjacent Victoria Island and Franz Joseph Land, the 'Decree on the Annexation of Lands and Islands Located in the Northern Arctic Ocean as Territory of the USSR of 15 April $1926^{20}$ ignored the Norwegian plea for full sovereignty over these areas. The Soviets pronounced as national territory the discovered and undiscovered islands east of a sector line from the western point of the former Soviet Union (Cape Niemetsky) to the North Pole. Until then, Franz Joseph Land was considered terra nullius.

This new territorial claim was notified to the Norwegian Government on 6 May 1926. Not only was Franz Joseph Land annexed, but the Soviet Union also made explicit its reservations against Norwegian statehood over Svalbard. ${ }^{21}$ The Norwegian reply of 19 December 1928 announced that these islands belonged to Norway:

The Norwegian Government hereby reserves its position regarding still not discovered islands ... and especially reserves its position with regard to Franz Joseph Land. This group of islands was first discovered by Norwegians... and was given the name of 'North East Spitsbergen. ${ }^{22}$

The Norwegian reply shows that Norway's sovereignty claim to the adjacent Franz Joseph Land was a territorial claim, unrelated to the 1920 Treaty of Svalbard.

The Soviet Union ignored Norway's claim to Franz Joseph Land, as no response was ever given. Besides, not a single objection by the international society of states - beyond Norway's negative reply - was made, and thus the Soviet Union's 1926 proclamation was tacitly recognised. The expelling of Norwegian vessels hunting for seals in Franz Joseph Land some few years later confirmed the formal situation. ${ }^{23}$

Even the Norwegian occupation of Victoria Island, close to, but beyond, the Svalbard Box, failed to gain international support. No single

20 For more details, see WE Butler, Northeast Arctic Passage (Sijthoff \& Noordhoff 1978) 174. For its present status in international law, see Peter Ørebech, "The Barents Sea 2010 Norway-Russia Border: The Triumph of the Negotiation Principle at the Expense of the Median- and Sector Line Pretentions' (2012) 4 Yearbook of Polar Law 505.

21 The Royal Norwegian Ministry of Foreign Affairs (UD jnr 12649/26 vol I) - Document in the Norwegian National Archive.

22 The Royal Norwegian Ministry of Foreign Affairs (UD jnr 19082/28 vol II) and the Russian reply (UD jnr 13269/30 vol IV) - Document in the Norwegian National Archive.

23 ibid. 
nation state was thus supportive of any attempt from Norway in its unilateral territory expansion.

\subsection{Theoretical, methodical and interpretational disagreements}

How to interpret the Svalbard Treaty text? Did the signatories and parties to the treaty intend to supply the international society of states with continuous power, overlooking Norway's initiation and implementation of jurisdiction? Is Norwegian sovereignty in need of recurrent confirmation? Is Norway, as of such restrictions, excluded from enjoying new developments in the Law of the Sea?

The focus here is on the concept of 'sovereignty' and 'territorial waters'. Several interpretative styles appear. Studying legal literature on Svalbard, the source of disagreement seems to substantiate diverse interpretative styles. Let us consider the different opinions.

The 1969 Vienna Convention on the Law of Treaties (VCLT) holds that if words are distinct, the natural reading of the texts decides the matter (article 31.1). In other words, we subscribe to the normal understanding of the utterances (the 'utterance meaning'). With this reading, the intention of the parties will be unleashed. A study conducted by Trygve Mathisen ${ }^{24}$ gives insights into the intent of the signatories, an issue further elaborated in parts $2.2,2.4$, and especially in 1.6. If textual interpretation is judicious, the interpretation process is successful and the valid legal rule is uncovered.

If disputed, the interpretation should consider the treaty's object and purpose (article 31.1), as well as conduct contextual analysis or supplementary means of interpretation such as the entire bulk of texts, preamble and annexes, additional commentaries that are treaty relevant and other instruments related to the treaty (article 31.2).

If still unclear due to obscurity or ambiguity, the judge has recourse to the "travail préparatoire" (article 32). It is appropriate to incorporate this legal source if the textual and contextual reading fails to produce a reasonable or acceptable result.

Static interpretation takes the contemporary reading at the time of origin as the basis, searching for the historical understanding of the disputed international law text.

Sometimes, concepts are dynamic legal standards, varying with changing times, often named 'evolutionary concepts'. Then, subsequent developments promote a changed understanding, including succeeding agreements or practices (article 31.3).

${ }_{24}$ Mathisen (n 15) 201ff. 
However, inter-temporal reading is inappropriate if it is at odds with the parties' intentions stated by the treaty's conclusion. Similarly, evolutionary reading is inapt in the case of discord with the treaty's object or purpose. Judge Rosalyn Higgins (ICJ) purported that 'evolutionary reading' cannot overrule the 'intention of the parties reflected by reference to object and purpose - that guides the law of treaties'. ${ }^{25}$ In the same way, Ian Sinclair advocates that if evolutionary interpretation is apt it '... must always be on condition that such an evolutionary interpretation does not conflict with the intentions and expectations of the parties as they may have been expressed during the negotiations preceding the conclusion of the treaty'. ${ }^{26}$

Sorting out which style is appropriate in interpreting different texts is challenging: case law prescribes that static interpretation is applicable when the dispute relates to juridical facts. A connotation is made when the text is interpreted in the light of contemporary law at the time of the signing and ratification of the treaty. One illustration is Judge Max Huber's statement: 'a juridical fact must be appreciated in the light of the law contemporary with it, and not of the law in force at the time when a dispute in regard to it arises or falls to be settled'. ${ }^{27}$ Another follows from Judge Klaestad's majority votum of 1960: 'It is sufficient to state that the validity of a treaty concluded as long ago as the last quarter of the eighteenth century... should not be judged upon the basis of practices and procedures which have since developed only gradually'. ${ }^{28}$ This excludes contemporary law at the time of the dispute settlement from being valid or relevant as a basis of interpretation.

This platform, however, does not eliminate all treaty texts from dynamic reading. As stated in the Island of Palmas case, inter-temporal law is pertinent in justifying the continuous manifestation of a right. This derives from the fact that ancient rules are modified over the years. This raises the issue of 'effectiveness'. It is, however, disputed whether this distinction is valid international law:

The arbitrator's reasoning seems to contradict the concept of title. If Spain owned the island in the $16^{\text {th }}$ century, then unless its ownership was displaced by another State, it should continue to be the owner. A mere change in the international rule regarding sovereignty over

\footnotetext{
25 Rosalyn Higgins, 'Some Observations on the Inter-Temporal Rule in International Law'. In Jerzy Makarczyk (ed), Essays in Honour of Krzystof Skubiszewski (Kluwer Law International 1996) 181.

${ }^{26}$ I Sinclair, The Vienna Convention on the Law of Treaties (Manchester University Press 1984) 140.

27 See Island of Palmas case (United States v the Netherlands) Perm Ct Arb, 2 UN Rep Intl Arb Awards 829 (1928) 845.

${ }_{28}$ Right of Passage over Indian Territory (Portugal v India) judgment, 12 April 1960, ICJ Rep 1960, 37.
} 
territories, without a factual change, should not suffice to change title. $^{29}$

Irrespective of the correctness of the Huber distinction, the concept of 'territorial waters' exemplifies both evolutionary and static law. Geographic reach has been altered over the years from the cannon width of 3 nautical miles as a maximum, creeping up to 4 nautical miles (in Denmark-Norway) and later to 12 nautical miles (the Soviet Union), which has also finally become the present international rule of law. While the notion in the jurisdictione ratione materiae stance is static and thus has remained unchanged over the years, the notion of 'territorial water' ratione terra is evolutionary. Otherwise, if the treaty parties had settled the width to 8 nautical miles as originally recommended, the provision would have been static.

\subsection{The principle of sovereign states' residual jurisdictional rights}

The principle of residual rights, which is the basis of the 1920 sovereignty theory that lies beneath the Svalbard Treaty provisions, is a basic principle of international law. If signatories maintained strict limitations on Norway's supremacy, they should have put them in writing. Any other approach is wishful thinking. Member States with ambitions for future maneuvering should have put off signing the treaty until they had the terms they wanted and should not by accession have subscribed to ' $n i$ condition ni reserve'. Future legislation would then acquire a joint ruling. However, no such claim was ever part of the treaty. No Norwegian legislation has resulted from joint rule (condominium), as will be further explained below.

Norway's position, as expressed by the Ministry of Justice, is as follows: 'It is my opinion that by accepting the Svalbard Treaty, Norway has acquiesced in binding legal rights to all proprietors, including Norwegians, as mentioned in Article 3'. ${ }^{30}$

Thus, one should differentiate between the present and future economic activity on the islands. The 1920 signatories expressed no ambition regarding future exploitation of resources, commerce or income flows to the benefit of their own subjects. Continuous utilisation and harvesting was granted, but new future activities were fully under the exclusive jurisdiction of Norway. Its future rule-making did not concern the signatories.

\footnotetext{
29 Anthony D'Amato, 'International Law, Intertemporal Problems' in Rudolf Bernhardt (ed), Encyclopedia of Public International Law (North-Holland Publishing 1992) 1235.

30 PM Law Department J No 108-26E by the Department Head of Division, Ministry of Justice, Mr Harbek of 27 December 1948 (JD Dc-0086, 1930-60, National Archive of Norway).
} 
Ulfstein posits that among Norwegian residual rights are 'activities not covered by the non-discrimination regime, [and] Norway has the right to prohibit and restrict activities on a discriminatory basis'. ${ }^{31}$ Accordingly, in the case of exploitation, activities and trades not previously carried out, Norway may retain Svalbard's harvesting gains for Norwegian subjects.

Against this backdrop, the framework of basic competences of sovereign states in general, and Norway's Svalbard competence in particular, should be resolved.

\section{5 'Judicial legislation': a lacuna-based system of law}

At times, conflicts trigger non-codified issues. Disputes arise out of lacunae, or loopholes in the law. Courts settle disputes with little or no basis in treaty language.

The geographic scope of the Svalbard Treaty is such an issue. Is nonliquet an answer? As told by ICJ Judge Vereshchtin, where lacunae exist, courts should not decide the issue. 'In advisory procedure, where the Court finds a lacuna in the law or finds the law to be imperfect', Vereshchtin stated, 'it ought merely to state this without trying to fill the lacuna or improve the law by way of judicial legislation'. ${ }^{32}$

International courts, however, refrain from adapting non-liquet responses. Judge Higgins' methodical approach is such an example. International law is a comprehensive system without loopholes. Instead, the judge's role is ...to decide which of two... norms is applicable ... As these rules indubitably exist, there can be no question of judicial legislation'. ${ }^{33}$ Judge Higgins meets the challenges of lacunae by applying customary or general principles of law. There is not always 'a clear and specific legal rule readily applicable to every international situation, but ... every international situation is capable of being determined as a matter of law'. ${ }^{34}$

These sources of law 'preclude the Court from pleading non liquet in any given case before it'. ${ }^{35}$ Max Huber set the norm in a 1928 Arbitrational Award:

For since an agreement's... object [is] to 'terminate' the dispute, it is the evident will of the Parties that the arbitral award shall not

31 Ulfstein (n 8) 290.

32 Vladen S Vereshchtin, Nuclear Weapons, Advisory opinion, ICJ Rep 1996, 280.

33 Rosalyn Higgins, Nuclear Weapons, Advisory opinion, ICJ Rep 1996.

34 R Jennings and A Watts (eds), Oppenheim's International Law (9 ${ }^{\text {th }}$ edn, vol 1, Longman 1992) 13.

35 TO Elias, The International Court of Justice and Some Contemporary Problems (Martinus Nijhoff Publishers 1983) 14. 
conclude by a 'non liquet', but shall in any event decide that the island forms a part of the territory of one or the other of two litigant Powers. ${ }^{36}$

The litigants of the Island of Palmas case make a parallel of the Svalbard dispute for the purposes of the ratione terrae issue. The right to establish an EEZ/FPZ and continental shelf surrounding Svalbard are either part of Norway's exclusive autonomy or are under the Svalbard regime. A third legal alternative - ie legal lacunae - does not exist.

\subsection{The interpretative style of treaties, the Svalbard Treaty in particular}

Article 31 VCLT is the basis: it provides that a 'treaty shall be interpreted in good faith in accordance with the ordinary meaning to be given to the terms of the treaty in their context and in the light of its object and purpose'. ${ }^{37}$ I subscribe to 'the primary necessity of interpreting an instrument in accordance with the intentions of the parties at the time of its conclusion'. ${ }^{38}$ What was the intention of the parties?

Jurisdiction is 'den Grundsatz der Volkssouveränität'. ${ }^{39}$ Besides, the 'doctrine of sovereignty in international law is superior to all others'. ${ }^{40}$ Although some jurists affirm the demise of sovereignty, there is no evidence to support this. On the contrary, sovereignty 'becomes greater every day', ${ }^{41}$ 'political and legal life'42 cannot survive without it. Whatever the realities of life, statehood and sovereignty remain 'rock solid' building blocks. Thus, in studying the 'extended reach' of the Svalbard Treaty, sovereignty is not at all in demise, but is rather the bedrock of international law.

A point of departure is that the Svalbard Treaty concept of sovereignty should be interpreted within the framework of the 1920s. At the end of WWI, new theories gained traction ${ }^{43}$ over Austin's static sovereignty

\footnotetext{
$36 \quad$ Island of Palmas (n 27) 869.

37 Arbitral Award of 31 July 1989 (Guinea-Bissau $v$ Senegal) ICJ Rep, 1991, 70: 'These principles are reflected in Articles 31 and 32 of the Vienna Convention on the Law of Treaties, which may in many respects be considered as a codification of existing customary international law'.

38 Ian Sinclair, The Vienna Convention on the Law of Treaties (2nd edn, Manchester University Press 1984) 139-140.

39 Hans Kelsen, Vom Wesen und Wert der Demokatie (Tübringen 1929) 32.

40 Sephan Hobe and Karsten Nowrot, 'Whither the Sovereign State?' (2007) 50 German Yearbook of International Law 243.

41 Wolfgang Friedman, The Changing Structure of International Law (Columbia University Press 1964) 35.

42 Ian Brownlie (ed), Basic Documents on Human Rights (Clarendon Press 1971) 1.

43 Butler (n 1).
} 
concept, ${ }^{44}$ ideas that however arrived too late to influence the Svalbard Treaty. Thus, the theoretical background contradicts the belief that signatories subscribed to an evolutionary interpretative style. My working hypothesis is that historic language reigns here (see part 2), which means ordinary meaning in the late 1910s.

Some jurists consider Svalbard a sui generis territory 'subject to a special international legal regime'. ${ }^{45}$ Presumably, this results from the oddity of its treaty-based jurisdiction, as opposed to the original jurisdiction acquired by occupation.

Professor Fleischer - former legal advisor to the Ministry of Foreign Affairs - objects: 'The argument that the Svalbard Treaty establishes a particular regime of a generally limited jurisdiction is baseless' ${ }^{46}$ I follow Fleischer.

The right to regulate economic activity is unlimited under the clear language of the Treaty, provided that Norway grants foreigners equal rights to Norwegian nationals: 'applicable equally to the nationals of all the High Contracting Parties without any exemption' (article 2). Similarly, article 3: '[e]qual liberty of access and entry ... to the waters, fjords and ports of the territories specified in article 1'. Article 3 repeats similar requirements ('equality'), article 7 ('complete equality') and article 4 ('absolute equality'). It is undisputed that Norway's non-discriminatory regulatory power jurisdictione ratione personae does not and cannot lead to the conclusion that Norway's jurisdiction is any less exclusive. Limited is not a synonym of shared.

Confusing jurisdictional rights with economic rights has engendered a misperception concerning Svalbard's alleged 'particular regime'. It is erroneous to say that Norway enjoys limited sovereignty. According to article 1 of the Treaty, it is the recognition of Norway's sovereignty, and not 'the full and absolute sovereignty of Norway' as such, which is 'subject to the stipulations of the present Treaty'.

The Treaty merely represents restrictions in specified legislative competences materially speaking, the most important being the requirement of non-discrimination. ${ }^{47}$

The ban on the discriminatory regulation of economic activities is an obligation of international law regarding the material content of legislation

\footnotetext{
44 John Austin, Lectures on Jurisprudence (vols I and VI, John Murray 1879).

45 Robin Churchill and Geir Ulfstein, 'The Disputed Maritime Zones Around Svalbard' in WE Butler (ed), Changes in the Artic Environment and the Law of the Sea (Panel IX, Martinus Nijhoff Publishers 2010) 565.

46 CA Fleischer, Petroleumsrett [Petroleum Law] (Universitetsforlaget 1983) 225; see also Ulfstein (n 8) 128.

47 Ulfstein (n 8) 128. See also page 436 'terra nullius non-discriminatory economic rights'.
} 
passed by Norway. Thus, discriminatory legislation would be in breach of the application of the Treaty, but not in breach of its jurisdictional powers. Thus, it limits Norway's legislative capacity. It neither alters nor reduces it, however. Norway has duly and legally enacted all the statutes governing the entire territory defined in the Treaty.

Why is the limited sovereignty argument implausible? The answer can be provided thus: [the] claim that Svalbard is ruled by a particular regime needs a foundation. Such a foundation does not exist. The Svalbard Treaty clearly states the opposite, namely that Norway enjoys "full and absolute sovereignty". ${ }^{48}$ I agree, as documented below.

The next analysis is based on the treaty ipso jure and ipso facto. Under article $77(3)$ LOSC, '[t]he rights of the coastal State over the continental shelf do not depend on occupation, effective or notional, or on any express proclamation'. I agree that under 'international law a state's territory automatically generates a continental shelf: it is not necessary for a state expressly to claim a continental shelf. ${ }^{49}$ Therefore, Norway benefits directly from the changes to LOSC, no differently from Russia, for example, with regard to its unilaterally annexed Franz Joseph Land.

Norway, like other sovereign states, enjoys residual rights to the remaining competences not limited by the responsibilities that Norway owes to the international society of states. In accordance with article 1 , it is only the implementation of sovereignty that is subject to certain stipulations under the treaty.

While Norway is a sovereign, and not a custodial state or one holding a mandate, not all the treaty terms are beyond dispute. Take the term 'full', for example. Article 1 of the treaty recognises the 'full and absolute' sovereignty of Norway over the Svalbard Box. Critics interpret 'full' to mean 'limited sovereignty' ${ }^{50}$ or 'semi-sovereignty'. ${ }^{51}$ Others construe 'full' to mean 'full and absolute'. ${ }^{2}$ The judicial competence of the Treaty suffers from ratione materiae, personae, temporae and terrae limitations.

\subsection{The Svalbard Treaty restrains Norwegian statutes}

Who possesses the competence to amend the Svalbard provisions on mining, trade, fishing and other harvesting activities? Is Norway's assignment unilateral?

The treaty text provides no one with either supervisory, review or amendment powers. Hence, since the contracting parties failed to agree

\footnotetext{
Fleischer (n 46) 224.

49 Churchill and Ulfstein (n 45) 561.

Ulfstein (n 8) 123.

Anderson (n 8) 15.

52 Fleischer (n 46) 224.
} 
to any particular framework constraining Norway's legislative competence, domestic Norwegian legislation ${ }^{53}$ is the valid instrument to handle changing situations.

Of course, limitations exist. Still, like everything else under the auspices of a treaty, disputes are subject to negotiations, arbitral awards or court decisions. Accordingly, the treaty does not support any states parties' claims to review Norway's domestic legislation or to provide them with mechanisms for doing so.

\subsubsection{The right to legislate. The treaty framework}

Parties to the treaty acknowledge 'the full and absolute sovereignty of Norway over the Archipelago of Spitsbergen' (article 1). The sovereign is the legislator. Jurisdiction and sovereignty are inseparable. Jurisdictional rights consist of three pillars: legislative, surveillance or enforcement, and dispute settlement rights. Norway indisputably enjoys jurisdictional rights in the Svalbard Box.

Article 2 concerns legislative competence. 'Norway shall be free to maintain, take or decree suitable measures'. Nationals of the High Contracting Parties in Svalbard enjoy hunting rights 'under conditions laid down by the local police regulations... [and] subject always to the observance of regulations made by the Norwegian Government'. This includes the right to set forth conditions for trade, mining, wildlife, and administrative tasks, for example. There are no restrictions on these rights. If Norway decides to regulate or ban a specific task, say by establishing a wildlife reserve like the one on Hopen, ${ }^{54}$ it can. No signatory or conventional party may interfere with that decision. The treaty does not restrict amendments nor does it set forth institutionalised procedures to report or confirm any.

However, the legislative power of Norway regarding subjects' right to engage in economic activity - to extract coal, fish, etc - is restricted. Norwegians cannot claim priority. On the contrary. All subjects of Treaty parties, regardless of nationality, place of registration, principal place of business, etc, enjoy equal harvesting and trading rights. In this respect, Norway's legislative power is limited. Still, within the harvesting and trade sector, Norway enjoys exclusive law-making autonomy, and power of surveillance and enforcement. It is up to Norway to draft tax statutes. Tax collected under the mining regime must serve the Svalbard

53 See the Svalbard Act of 17 July 1925 § 1: 'Svalbard is a part of the Kingdom of Norway'; the Statute of 3 June 1977 on the 200 nautical miles' Fisheries Protection Zone at Svalbard; the Act of 17 December 1976 on the Norwegian Exclusive Economic Zone; and the continental shelf by Norwegian Decree in 1963. Cf the Act on Exploration and Exploitation of Sub-sea Natural Resources of 21 June 1963.

54 Rt 2008, 1747 Northlight Oil AS and Plexus Investments USA, Inc. 
community: "Taxes, dues and duties levied shall be devoted exclusively to the said territories and shall not exceed what is required for the object in view' (article 8.2).

With regard to policing, surveillance, control and enforcement, Norway enjoys exclusive autonomy of authority. As made clear in paragraph 9 of Annex 1 and paragraph 1 of Annex 2, Norway enjoys enforcement power 'in accordance with the laws and regulations in force or to be enforced in the territories specified in Article 1 of the present Treaty'. An illustration is $\S 29$ of the Regulation concerning the Management of Wildlife in Svalbard of 24 May 1996: The Governor is responsible for seeing to it that the provisions are complied with, and can, in that connection, issue more detailed provisions concerning control and supervision of hunting activities'. ${ }^{55}$

The Treaty does not restrict this jurisdiction. Thus, the right to oversee and enforce all enacted laws and regulations complements the right to legislate as outlined in article 1. Norway's ongoing enforcement practice on land has continued without objections. Offshore, in the FPZ, frustration is more common. The Norwegian Supreme Court fisheries cases of 1996, 2001 and 2006 demonstrate this. ${ }^{56}$

In addition, dispute settlement belongs to Norwegian courts. The Act of 17 July 1925 relating to Svalbard proclaims that legal courts are those which the King determines (§§ 6 and 7). The King's Resolution of 9 October 1925 applies this power. ${ }^{57}$

This system has worked well for a long time. The contracting parties, with few official protests, tacitly acknowledge this. ${ }^{58}$ Thus, as is explicitly stated, Norway's sovereignty is not conditional and does not differ from the sovereignty of other nation states. It is unrestricted with regard to the process of legal decision making.

\subsubsection{Economic rights - material limitations}

Rights to exploitation, harvesting and other traditional activities on Svalbard are open to all citizens of the member states of the Treaty on an equal basis. Guarantees of non-discrimination of member states' citizens conducting economic activity appear throughout the Treaty. 'These measures shall always be applicable equally to the nationals of all the High

\footnotetext{
55 Repealed by 1 July 2002.

56 Rt 1996, 624 (Iceland), Rt. 2001, 1172 (Russia and Great Britain) and Rt. 2006, 1498 (Spain).

57 Kgl res of 8 March 1985 on the Svalbard judicial jurisdiction subsequently replaced it.

58 My study of the dossier of the Ministry of Foreign Affairs in the Public Record Office during the period 1917-1936 found only a few notes or aide memoires expressing disagreement or protests.
} 
Contracting Parties without any exemption' (article 2). 'The nationals of all the High Contracting Parties shall have equal liberty of access and entry for any reason or object whatever to the waters, fjords and ports of the territories specified in Article 1' (article 3). At other points in the Treaty text, the concepts of 'complete equality' (article 7) and 'absolute equality' (articles 3 and 4) are all guaranteed. It is commonly understood that beyond the particular issues barring discrimination on grounds of nationality, Norway enjoys unlimited jurisdiction. ${ }^{59}$

The Treaty's parties are nation states, and not their citizens. Having no standing, the citizens of a contracting party cannot raise an issue before the ICJ alleging that Norway is breaching its treaty obligations. 'Other nation states are the beneficiaries of an international law requirement that Norway treat those states' citizens and companies in accordance with the Treaty requirements'. ${ }^{60}$ Thus, natural persons and legal persons such as business entities must seek recourse to their nation state.

The French position holds that the citizens of all the Signatories will have the same fishing and hunting rights ... This is an important limitation on sovereignty which should erase all doubts on approving the treaty, if any remain'. ${ }^{61}$ While the French language does not explicitly reserve non-discriminatory benefits to subjects already possessing lands, exploiting natural resources or conducting trade or industries in Svalbard, the reference to contracting parties' citizens refers to the present inhabitants and not persons in spe. Nonetheless, the French parliament explicitly limits the benefit to the areas within the territorial sea. In the case of more extensive geographic ambitions, the claimants' duty was to clarify them.

The US position is as follows:

The treaty ...offers a satisfactory and a practical solution of the long-standing and vexatious questions relating to the sovereignty of the archipelago... It appears to be desirable that the United States should acquiesce in an arrangement to recognize the sovereignty of Norway over Spitzbergen. ${ }^{62}$

\footnotetext{
59 Ulfstein (n 8) 265-67.

60 NOU 1990:10 Ny lov om skatt til Svalbard [A New Tax Code for Svalbard]. Other member states benefit from an international legal right to see that their subjects are treated according to the treaty.

61 Chambre des Députés, Session de 1924: Rapport fait au nom de la Commission des Affaires Etrangères. Chargée d'examiner le Projet de Loi Portant approbation de traité relative au Spitzberg, signé à Paris le 9 février 1920, 16. Citation taken from the Archive of the Norwegian Ministry of Foreign Affairs (UD jnr 20970/1924) in the Norway National Archive, Box JD, Dc-0084.

62 Congressional Record, vol 65, 18 February 1924 no 51, 2651 (Senate).
} 
In a communique to the Norwegian government, the US stated that '[the] Government of the United States of America is in full accord with that of Great Britain in that it has no political interest in Spitzbergen'. ${ }^{63}$

Non-signatories like Germany supported the Norwegian position:

[the] German Deputy Minister of Foreign Affairs recognizes the Norwegian position and will not oppose it if the Entente accepts it during the Paris Peace Conference provided that German economic interests are guaranteed. ${ }^{64}$

The verb 'to be' is in the present tense. Germany did not use "will be" to indicate guaranteed economic interests forever. Germany could just as easily have stated, "provided that German economic interests are and will be guaranteed'. It did not. Again, the foreign concern is to protect the present foreign citizens' present economic rights. ${ }^{65}$

Only citizens' 'then existing' enjoy equal rights protection. Thus, since none of the treaty parties were engaged in deep-sea mining, oil drilling, or high-seas fishing in 1920, none of these new activities enjoy protection. In the same way, marine areas beyond the territorial waters of Svalbard are excluded from the treaty. ${ }^{66}$

\section{The Svalbard Treaty}

\subsection{Full and absolute sovereignty: a special regime}

the evolution and development of the law can be taken into account in interpreting ... such general terms as to lend themselves to an evolutionary interpretation ... [T] his must always be on condition that such an evolutionary interpretation does not conflict with the intentions and expectations of the parties as they may have been expressed during the negotiations preceding the conclusion of the treaty'.

Ian Sinclair ${ }^{67}$

\footnotetext{
63 Promemoria JD Jnr 110/1925: Dr juris Arnold Ræstad; Staten og den ikke-okkuperte grunn på Svalbard [The Government and the Non-occupied Ground in Svalbard] (13 September 1924) 23.

64 The Norway National Archive, Ministry of Foreign Affairs, Box 6166A. P1- settlement of international disputes L, League of Nations, XII, International Agencies, P2 War and Neutrality: Code-telegram (No 202) 26 April 1919, from the Norwegian Legacy in Berlin to the Ministry of Foreign Affairs.

65 As confirmed by the Norwegian Supreme Court, in the 'Fischfang' case Rt 2014, 272.

66 Ulfstein (n 8) 441.

67 Sinclair (n 26) 140.
} 
The basic issue is the significance of Norwegian sovereignty over Svalbard. What is the meaning of 'sovereignty' and 'full and absolute'? Does the first concept cover all issues of legal and economic rights, ie jurisdiction as well as harvesting rights, and does the latter notion denote 'unlimited and exclusive'?

Since most researchers reject terra nullius, or mandate and custodial pacts under the auspices of Norway, and since it is unnecessary to state the obvious, this part of the paper shows whether Svalbard is a special sovereignty system solely, as maintained by opponents to the Norwegian position: 'Norway's sovereignty over the territories ...went hand in hand with a special regime (un régime équitable propre ...)'. ${ }^{68}$ Thus, what is so special about Norway in executing its sovereignty?

The focus of this section is whether the treaty establishes a peculiar type of sovereignty and, if not, whether the concept of 'full and absolute sovereignty' is 'evolutionary' or 'historic'. Another issue of interest is whether transfer of sovereignty is a 'one-time thing', or in need of continuous confirmation. I further ask whether this 'peculiar type' to which several researchers subscribe trumps jurisdictional rights pursuant to some other basic legal sources such as customary or general principles of law. This raises the question about whether Norwegian sovereignty is nothing but a special or a mutatis mutandis regime.

As stated, Norway enjoys 'full and absolute sovereignty' over the archipelago. There is no limitation to Norway's sovereignty in this. This position is made even more vibrant in the French text. As interpretation shows, the signatories in the French version of the treaty express that they 'sont d'accord pour reconnaitre' ['agree to recognise'] Norwegian sovereignty (see article 10). Thus, sovereignty - the existence of which Norway claimed ex tunc - was acknowledged by the signatories by ratification of the 1920 Treaty. There is no review or withdrawal mechanism. This clarifies that the transfer of jurisdiction was a one-time thing.

By 14 August 1925 all signatories had assented to Norway's exclusive autonomy over Svalbard. The ratifications were unconditional, $\mathrm{cf}$ ' $n i$ condition ni reserve'. No one claimed any time limitations or other modifications to the Norwegian jurisdiction. Thus, the treaty was concluded for unlimited duration.

No form of condominium was ever recommended. Neither was any later recurring ratification of the sovereignty nor of any permanent system of recognition of domestic Norwegian legislation regarding the Svalbard population or businesses.

Clearly, it is easily conceived that the treaty text recognised by the parties invariably expresses the irrevocable sovereignty of Norway.

68 Anderson (n 7) 2. 
Norwegian policy claims absolute sovereignty rule over the archipelago. ${ }^{69}$ Consequently, Norway insists that the Treaty terms set forth a territorial framework, not only for 1920 but also for all time: Norway's sovereignty in the Svalbard Box is irrevocable.

The treaty's founding fathers used conventional language - ie 'the ordinary meaning' of words. I cannot conclude but that 'full and absolute sovereignty' is a generic utterance. It contains - for the time being - acknowledged competences as framed by international law. Norway, like other coastal states, enjoys residual rights (see part 1.4) which are limited by acknowledged international laws solely. The treaty text inserts neither a special nor a mutatis mutandis regime.

\section{2 'Territorial waters': the geographic scope}

'That would be a strange result: in the law of the sea, rights diminish, not increase, as one moves outwards from the coast'. ${ }^{70}$

The focus here is twofold: first, to investigate entitlements for a terrestrial extension of the Svalbard Treaty. Second, to compare the alleged Norway restrictions beyond the territorial sea with the US extension of the three-nautical-mile zone of exclusive harvesting rights that the several states or their inhabitants hold.

My hypothesis is that divergent views on the Treaty's 'geographic scope' result from the following: first, controversies regarding the underlying presumption. Critics (also called opponents in this paper) refuse to recognise residual rights as a platform for all reasoning regarding sovereign state jurisdiction. Second, they refuse to relate the disputed 'geographic scope' to the correct legal basis. The geographic scope of the Treaty is clearly set out in the Treaty. The lack of mention of marine areas beyond the territorial waters is obvious, as the conclusion of the Treaty precedes even the vaguest forecast on the developments of the present law of the sea. This being the case, the question is what the legal basis is for the establishment of the Svalbard FPZ, and if there is some other legal basis for arguing that the Svalbard Treaty provisions apply even beyond the geographic scope of the Treaty. Third, critics confuse jurisdictional rights with economic rights, ie the 'right of other nations in mining and

69 On Norway's position, see Rolf Fife, 'Svalbard and the Surrounding Maritime Areas: Background and Legal Issues - Frequently Asked Questions' <www.regjeringen.no/en/dep/ ud/selected-topics / civil--rights/spesiell-folkeett/folkerettslige-sporsmal-i-tilknytning-ti. html?id=537481 $>$ accessed 16 May 2014. For a supportive position, see also Fleischer (n 46) $295 \mathrm{ff}$.

70 Anderson (n 7) 15. 
trade', ${ }^{71}$ that is, the nationals of the Parties. Fourth, critics wrongly claim that the Svalbard Treaty - in general - should be interpreted according to a dynamic evolutionary reading or analogy.

Thus, the salient point is whether the Svalbard Treaty suffers from lenient textual interpretation and too shallow investigations which collide with the intentions of the signatories to the treaty.

The Treaty's terrestrial scope is clear cut, ie the Svalbard Box (article 1). No text approves of Norwegian jurisdiction beyond the Box. Neither does practice as revealed in part 1 . Since treaty law does not resolve the issue of geographic scope, Norwegian powers with regard to the marine areas beyond the territorial waters of Svalbard result from customary or general principles of law, and not treaty law.

The treaty refrains from stipulating whether Norway could, according to the Treaty text, enjoy exclusive control over areas beyond the Svalbard Box. Thus, Norway's offshore entitlements must result from general legal development, and not from the Treaty itself:

Consonantly with the wording of art. 1 of the Svalbard Treaty... Norway was granted an ordinary sovereignty, i.e. similar to territorial sovereignty based on customary international law. This means that in principle the rights of other states under the Svalbard Treaty should be determined as if Norway had granted [them] such rights as a territorial sovereign. ${ }^{72}$

My position is that there is a legal solution to the Treaty's disputed 'geographic scope'. Do Svalbard 'territorial waters' really cover not only the EEZ but also the continental shelf? The challenge is to determine the relevant sources of law. As the Treaty text is inadequate, customary or general principles of law apply. Due to this very fact, one simply cannot subscribe to a position of the description of the geographic delimitation as a generic-referring expression with a referent assumed to be alterable.

\subsection{The treaty text contribution and preparatory work}

With the advantage of hindsight, states parties advancing arguments about ratione terrae would have presented their views to the plenipotentiaries before signing the Treaty. However, at the present time, views on the Treaty's possibly extended geographic scope appear as de scententia ferenda.

Examining geographic reach, the 'travail préparatoire' is a vital interpretative factor. The trilateral draft convention (Norway, Russia and

\footnotetext{
71 As already clarified in 1927: Chambers's Encyclopædia. A Dictionary of Universal Knowledge (W \& R Chambers 1927) 604.

72 Ulfstein (n 8) 469.
} 
Sweden $)^{73}$ proposed an 8 nautical mile territorial sea, leaving no discretionary power to Norway. Norway had a duty to comply. In this case, if the 8 nautical miles had become the final result, even more outcomes would have followed from this very fact. I here fully subscribe to the Linderfalk position to the dispute settlement in the delimitation case between the United Kingdom and Germany: ${ }^{74}$ 'After all, the whole point of entering into a boundary agreement is to establish once and for all the location of a common boundary'. ${ }^{75}$

However, the 8 nautical miles limit never became the end result. The Dutch government referred to the proposed limit as a 'slip of the pen'. ${ }^{76}$

There was no mistake, however. Instead, the 8-mile compromise was a half-way solution between the 12-mile zone sought by the Soviets and the 4-mile Norway zone. ${ }^{77}$ However, at the second Trilateral Treaty Conference, Great Britain ${ }^{78}$ and France ${ }^{79}$ objected to the 8 -mile rule. Thus, the parties failed to reach agreement on geographic reach. As a result, the Signatories assigned and entrusted to Norway the right to decide the issue. This is confirmed by subsequent practice: Norway, to no opposition, unilaterally established its straight baselines, fixed its territorial sea at 4 nautical miles, and in 2006, expanded it to 12 nautical miles. Thus, the international society of states acknowledged that the width of the territorial sea falls fully under the unilateral decision of Norway.

How to solve the geographic scope? The historical background gives us a clue. In the mid and late 1920s, several international conferences took place to finalise the disputed issues of the reach of the archipelagic waters in general. Since - as proposed - the archipelago could foster 'straight baselines', some of which extended to twice the breath of an ordinary territorial sea, the absence of any discussion on the matter seems to indicate that the Paris Peace Treaty conference on Svalbard declined to grant to Norway any exact stipulation of the archipelagic sea that, according to the law of the sea, was not clearly defined at that time. ${ }^{80}$ While

\footnotetext{
73 Mathisen (n 15) 113ff.

74 Kasikili/Sedudu Island (Botswana/Namibia), Judgment of 13 December 1999, ICJ Reports, 1999(II) 1045ff.

75 Ulf Linderfalk, 'On the Understanding of Treaties: The Modern International Law as Expressed in the 1969 Vienna Convention on the Law of Treaties' (Law and Philosophy Library 83, Springer 2007) 91 (emphasis added).

76 Mathisen (n 15) 113ff.

77 ibid, 128.

78 ibid, 133.

79 ibid, 135, fn 5.

80 CF Amerasinghe, 'The Problem of Archipelagoes in the International Law of the Sea' (1974) 23 International and Comparative Law Quarterly 539, 541-43, referring to conferences, ie (1926) 20 AJIL Spec Suppl 318, 319; (1928) 34 Annuaire de I'lnstitut de droil international, 673; and (1929) 2 Series League of Nations 51.
} 
the parties refrained from stipulating the exact reach of the territorial sea, the signatories did not waive the latter well-recognised and more or less defined offshore area. The heavily disputed archipelagic water, on the other hand, remained unresolved. The same is true of possible future developments of the coastal states' exclusive harvesting right on its continental shelf. ${ }^{81}$ The parties simply did not consider them.

Deciding on an EEZ was beyond the 1920 Treaty text. Hence, the founding parties delegated to Norway the power to decide whether to establish an EEZ, FPZ or simply to refrain from establishing any zone at all. While 200 nautical miles is the maximum allowed, Norway in its discretion may opt for less all-embracing zones. Few object to this, cf the establishment of an FPZ in 1977. The key issue then is whether the treaty limitations on Norwegian sovereignty pertain to these waters and the continental shelf. Again, the answer to this issue depends on whether customary law and general principles of law distinguish between different ways of territorial acquisition regarding sovereignty once obtained, ie whether sovereignty is acquired through original treaty-based occupation or annexation.

\subsection{Methodical issues: the Vienna Convention}

How to interpret the 1920 Svalbard Treaty jurisdictione ratione terrae? While the 'territorial sea' extension was not fully determined in international law, the contiguous zone belonged to the future. While an expansion from 3 nautical miles to 8 or even 12, territorial sea was not contradictory to 'the ordinary meaning' of 'territorial waters', quite another type of jurisdiction occurred with the launch of the EEZ. The introduction of the innovative law of the sea exclusive harvesting zone of 200 nautical miles and a 'continental shelf' had been impossible to predict.

Thus, whether the 'restrictive approach' is 'old-fashioned' is irrelevant because the Treaty is a WWI product. The 1920 Treaty has not hampered unilateral Norwegian decisions on the reach of the territorial waters. Clearly, the 'territorial sea' of Svalbard has 'evolved' from 4 nautical miles to 12 nautical miles in accordance with the development of the law of the sea. 'Territorial waters' is a distinct concept which can never 'enhance' or be interpreted dynamically to include other types of marine areas like fisheries zones, marine protection zones, exclusive economic zones, etc, unless it is made evident that the parties intended to deviate from the ordinary meaning of the term 'territorial waters'. As is well known, the 1958 Geneva Convention on the high seas refrained from acknowledging South American claims to an inflated national zone up to

81 Cecil Hurst, 'Whose is the Bed of the Sea' (1923) 34 British Yearbook of International Law. 
250 nautical miles from the baselines. It was in the early 1970s that the exclusive economic zone was first introduced.

Since 'territorial' water used in the Svalbard Treaty is a 'generic term', describing a jurisdictional system of complete coastal state autonomy with the exception of 'innocent passage', the concept cannot 'evolve' over time to include marine areas beyond the LOSC 12 nautical miles maximum territorial waters embracing the jurisdictional power of quite another type than the first. Thus, treaty terms should be read in the light of their ordinary historical meaning at the time of the treaty making. Applying evolutionary concepts turns the 1920 meaning upside down, because these concepts are based on legal requirements adopted long after the drafting of the treaty.

'Evolutionary concepts' are not flawed or without basis in law. Not at all. They are viable and interpretative methods in cases where parties affirmatively indicate that some treaty terms are subject to 'dynamic interpretation' if that is their intention. In the case of Svalbard, this is the pertinent illustration: 'territorial sea' is, substantially speaking, static. When it comes to 'geographic reach', the treaty should be interpreted in the light of the development of international law, and is thus dynamic.

Such interpretation will then replace the default legal standard the 'contemporaneity principle' - and become the legal standard set by the living fabric of life, ${ }^{82}$ or 'changing social needs'. ${ }^{83}$ The question here, therefore, is whether the Svalbard Treaty text demonstrates an intended special meaning of the Treaty's geographic reach.

If the Treaty text and travaux préparatoires fail to solve the matter, customary and general principles of law are a subordinate source of law that can come to the rescue (ICJ statute, article 38.1). Since there is no evidence to show otherwise, the parties to the Svalbard Treaty have left lacunae to be resolved by customary and general principles of law.

Case law and the writings of distinguished jurists are the very last resort to repair loopholes left by conventional, customary, or general principles of law (ICJ statute, article 38(1)d).

Consequently, the 'logical'84 or "natural'85 view on the validity of the terrestrial scope of the Treaty are not the decisive arguments, as some jurist have presumed.

\footnotetext{
82 Brad Snyder, 'The House that Built Holmes' (2012) 30(3) Law \& History Review 661, 706. The author presents this famous statement of the US Supreme Court Justice Oliver Wendell Holmes in its historical context.

83 Ulfstein (n 8) 87.

84 Anderson (n 7).

85 Ulfstein (n 8) 125, 127, 140, 366, 411, 424, 429, 479.
} 
Treaty parties may - if it is documented that parties intended to give a special meaning to a term - subscribe to a particular interpretative method (article 31.4 VCLT), one that differs from the method used when applying general principles of law expressed in the ICJ Statute. The issue in casu is whether the 1920 Treaty provides for particular interpretative methods set forth by the signatory states. The answer is no. There are no treaty provisions that contradict general interpretation principles as set forth in the VCLT. Thus, these codified customary law principles in the VCLT apply to the Svalbard Treaty.

\subsection{An interpretative approach}

'[In] the law of treaties ... the intention of the parties is really the key ... [a] wider principle - intention of the parties reflected by reference to object and purpose - that guides the law of treaties'.

Rosalyn Higgins ${ }^{86}$

The issue for discussion is whether the Svalbard Treaty text imposes inter-temporal reading:

Mindful as it is of the primary necessity of interpreting an instrument in accordance with the intentions of the parties at the time of its conclusion, the Court is bound to take into account the fact that the concepts ... 'the strenuous conditions of the modern world' and 'the well-being and development' of the peoples concerned - were not static, but were by definition evolutionary. ${ }^{87}$

We need to consider how the interpretative style contributes to the understanding of a possible geographic scope of the Svalbard Treaty. In this part, I return to the discussion begun in part 1.3 on the evolutionary reading of texts.

How to interpret the treaty text concerning the ratione terrae inquiry? ${ }^{88}$ The contracting parties control not only the substantive provisions of the treaty, but also the method of interpreting it. As demonstrated, the 'contemporaneity principle' is the legal standard for treaty interpretation.

\footnotetext{
86 Rosalyn Higgins, 'Some Observations on the Inter-Temporal Rule in International Law' in Jerzy Makarczyk (ed), Essays in Honour of Krzysztof Skubiszewski (Brill 1996).

87 Legal consequences for states of the continued presence of South Africa in Namibia (South-West Africa) notwithstanding Security Council resolution 276 (1970), Advisory Opinion of 21 June 1971 ICJ Reports $1971 \S 53$.

88 For a general and comprehensive study, see eg ES Yambrusic, Treaty InterpretationTheory and Reality (University Press of America 1986).
} 
A criticism of the Norwegian position regarding the geographic scope of the Treaty is that the 'Norwegian government's argument ignores the second [Treaty context] and third [the Treaty's object and purpose] of those elements' prescribed in the interpretative rules in article 31(1) VCLT. ${ }^{89}$ Alas, these critics do not give reasons for their position.

Undoubtedly, the judge's basic task is to search for '[the parties'] intention as expressed in the words used by them in the light of the surrounding circumstances'. ${ }^{90}$ It is possible that the parties to any treaty express no particular intention in its text with regard to the issue in question. Here, that issue is the geographic scope of the Svalbard Treaty, a topic never addressed by the contracting parties. Where the parties express no intent, you cannot deduce one from the treaty language: neither from its context, nor from its object or purpose.

Alternatively, as the Norwegian government has clearly put forth, one has reason to believe that the signatories' disinterest in the future legal or political development indicates that the societies of states in 1920 had no intention of blocking or barring Norway from reaping the benefits of the new developments of international law.

Accession is one thing, and amendment procedures are another. Amending the treaty's territorial frame entails consensus. In the words of Fleischer:

The islands and territorial sea located within 4 nautical miles outside of the straight baselines are Norwegian. ... All coastal states seem to support the law introducing an economic zone of 200 miles, which includes their entire coastlines. Thus, the existence of a zone that covers the entire Spitsbergen is based upon a legal principle like that of the zone surrounding continental Norway. ${ }^{91}$

Thus, the official Norway position is that the legal basis for Svalbard FPZ is nothing other than the 1982 Law of the Sea Convention (LOSC), in effect since 16 November $1996 .{ }^{92}$ Since coastal states may establish 'more', ie EEZ, it may do what is 'less', ie EFZ or EPZ.

The opponents of Norway's position on the limited geographic scope of the Treaty reject that Norway possesses either a national continental shelf or an exclusive economic zone beyond the Svalbard territorial sea. ${ }^{93}$

\footnotetext{
89 Churchill and Ulfstein (n 45) 567.

90 AD McNair, The Law of Treaties (2nd edn, Oxford 1961) 365.

91 CA Fleischer, 'Le Régime d'exploitation de Spitsberg (Svalbard)' (1978) 24 Annuaire Français de Droit International 295-297.

92 The United Nations Convention of 10 December 1982 on the Law of the Sea, 1833 UNTS,

21 ILM 1262 (1982).

93 Ulfstein (n 8) 440-41; Anderson (n 7) 14-15.
} 
The significance of the opponents' position relies on treaty interpretation, ie the literal meaning of the words and terms expressed in the Treaty, as understood by the interpreters' consideration of what is 'natural' ${ }^{94}$ or 'logical'. ${ }^{95}$ This results from the de lege lata analysis and makes amendment procedures unnecessary.

However, neither 'logical' nor 'natural' applications are valid interpretative factors under article 31 VCLT or sources of international law according to article 38 of the ICJ Statute. On the contrary, logical and natural application are, as a matter of legal sources, ranked inferior to text, context, traveaux préparatoires, the parties' intentions, and customary or general principles of law.

Of course 'logical' or 'natural' application may qualify as de sentential ferenda statements. However, although these applications express nothing more than the $21^{\text {st }}$ century interests of the parties advancing them, they still do not apply here.

Which circumstances or privileges caused the contracting states parties to set aside their unanimous, strictly literal, textual and contextual interpretation of their own provisions and to adopt the interpretation they now champion? This newly proposed understanding is an 'unleashed', unassigned de sentential ferenda legislative approach. It argues for an unlimited geographic reach - somehow - even though the clear treaty language provides just the opposite. The old contracting parties have a name for their brand-new interpretative approach called 'dynamic interpretation'. ${ }^{96}$ It is claimed that the solution 'must depend on a concrete assessment of the question under interpretation', ${ }^{97}$ in the light of the current situation.

As the text and context indicate, the equitable regime relates to economic access prohibiting nationality-based legal discrimination and guaranteeing equal rights to harvest and trade in the treaty area. The main purpose of the signatories was to protect: (i) the present economic rights of subjects of nation states, where present means at treaty-making time; and (ii) the status quo. The Treaty sought to guarantee existing rights and not to allocate potential new rights to these subjects. The 'equitable regime' relates and refers to going concerns.

The Treaty includes no signs of evolutionary concepts. If Norway obtained final sovereignty over Svalbard, which is Norway's position, ${ }^{98}$

\footnotetext{
94 Ulfstein (n 8) 125, 127, 140, 366, 411, 424, 429, 479.

95 Anderson (n 7).

96 Ulfstein (n 8) 89.

97 ibid, 88.

98 St meld nr 39 (1974-75) Vedrørende Svalbard [On Svalbard] 7: By the Svalbard Treaty, Norway has finally retrieved sovereignty over Svalbard.
} 
no differently from the sovereignty obtained and claimed by other landmasses around the globe, then the context is quite different, as is the reasonable interpretation.

My interpretation of the same fact is the following: originally, the Spitsbergen Commission proposed a fixed territorial sea of 8 nautical miles. The end result was no specification at all: thus, Norway, the possessor of residual rights, enjoyed unilateral, domestic law competence with regard to the width of the territorial sea. Instead of determining the exact straight-line distance from the baseline for Norway to adjust to, the territorial sea was undetermined and thus Norway was left to decide it unilaterally - within the maximum limit of international law.

Because Norway held 'full and absolute sovereignty' (article 1), the signatories entrusted Norway with the 'legal dynamics'. Once acquired, Svalbard is governed by the domestic law of the sovereign state of Norway. Norway, like other coastal states, enjoys the rewards of the general development of the law of the sea.

Thus, recognition was a one-time thing. Consequently, one simply cannot subscribe to a position of the description of the geographic delimitation as a generic-referring expression with a referent assumed to be alterable.

Visibly, it can be easily conceived that the treaty text recognised by the parties invariably expresses the irrevocable sovereignty of Norway. The Svalbard case is clearly not comparable with the arbitrational award in La Bretagne, ${ }^{99}$ characterising the concept of 'fishery regulation' as a non-generic legal standard. I thus subscribe to the Linderfalk position as referred to above. ${ }^{100}$

\subsection{Substantial issues: does case law give a clue?}

Judicial precedent is a valid source of law. What is the nature of the territorial sea and 'nature of the continental shelf as a territorial extension'? Do these arguments apply directly to the issue of the geographic scope of the treaty? Are they instead only of slight relevance because the analogies are not to the point? My primary interest is whether the facts of these cases - as claimed by some critics to the Norwegian position - cover instances that are analogous and thus relevant to the Svalbard Box. Secondly, this article seeks to determine whether case law is relevant to the Svalbard issue of geographic scope.

\footnotetext{
99 Dispute Concerning Filleting within the Gulf of St Lawrence (Canada/France), Award of 17 July 1986, ILR vol 82, 591ff (hereinafter: the La Bretagne case).

100 Linderfalk (n 75) 91.
} 
One case referred to by critics of the Norway position is the Permanent Court of Arbitration in the Grisbadarna case (1909). ${ }^{101}$ At issue was the delimitation of a certain part of the maritime boundary between Norway and Sweden. Norway had transferred the county of Bohuslen to Sweden by treaty in 1661 .

The legal issue that parallels Svalbard was whether or how to give effect to the 1661 Bohuslen Treaty that guaranteed the continuous validity of ancient Norwegian (St Olav) laws. ${ }^{102}$ One basic principle of these laws was open access to the outer fisheries commons. The Svalbard Treaty parallel puzzle is whether the treaty that guaranteed all inhabitants of Bohuslen County previous rights for all time should also apply to waters beyond territorial waters due to the law of the sea (LOS) advances in the 1970s.

At issue was how to construe the 1661 treaty term - to the limit of the territorial waters - in 1909. The treaty text directed the court in its detection of the maritime boundary line between the litigants Norway and Sweden. As a point of departure, the court determined 'from the evidence' that the parties had not intended 'to fix in advance the terminal point of the boundary'. The court decided the case based on facts and international law.

Despite the opponents' assertion, case law fails to support their reasons on the terrestrial issue. Instead, they support Norway's position on the Svalbard Box.

As for the non-binding dicta, what possible relevance can the Grisbadarna case have when read in connection with the Aegean Sea Continental Shelf and the North Sea Continental Shelf cases? While the 'continuous nature of the continental shelf as a territorial extension' is stressed in the Aegean Sea case and in the North Sea case, the perspective of the Grisbadarna case is different. ${ }^{103}$

As the award shows, the court rejected a possible intrinsic connection between the sea and the land territory and further rejected the alleged connection between the sea beyond the ancient borderline of 1661 and the new one made in 1909. The court held that the marine territory 'presents numerous peculiarities which distinguish it from the land territory'. Altogether, the contracting parties had not set the boundary from the land to the sea ('territorial extension'). They had done just the opposite. 'In determining the boundary line', the contracting parties had gone in a direction from the sea toward the coast. ${ }^{104}$

\footnotetext{
101 The Grisbadarna case (Norway v Sweden) Hague Ct Rep (Perm Ct Arb 1909).

102 Knut Robberstad, Rettsoge bd I [Legal History, vol I] (Universitetsforlaget 1971) 231.

103 Grisbadarna (n 101) 128.

104 Grisbadarna (n 101) 128 (emphasis added).
} 
The next question is whether the Aegean ${ }^{105}$ or the North Sea case ${ }^{106}$ can serve, as the critics of Norway claim, as precedents regarding the 'geographic scope' of the Svalbard Treaty.

The 1969 North Sea case decided the delimitation of opposite and adjacent territories of Denmark, the Netherlands and Germany. The parties 'had asked the Court to declare the principles and rules of international law applicable to the delimitation' of the North Sea continental shelf. ${ }^{107}$ On the face of it, the facts of the cases are not at all similar, much less identical to the treaty facts. Nevertheless, in deciding the issue, the court may have considered customary or general law principles upon which maritime issues are regulated in a much broader sense.

The North Sea case, as it happens, is irrelevant for determining the Svalbard geographic scope. This case discusses the zone and shelf in the light of the 'geographical configuration of the coastlines of the countries whose continental shelves are to be delimited'. ${ }^{108}$ The court's position is that one cannot ignore the configuration of the coast because the shelf is 'evocative of the land and not of the sea'. ${ }^{109}$ These remarks relate to the configuration of the land and thus the parallel delimitation offshore, meaning the borderline between opposite and adjacent states. As stated, 'the Court has examined the problems raised by the present case in its own context, which is strictly that of delimitation'. ${ }^{110}$

Thus, the context of the Svalbard case is not remotely analogous. The North Sea case does not address substantive law governing the jurisdictional powers of the coastal states within the EEZ or the continental shelf.

The court's ratio decidendi focuses on the importance of 'natural prolongation' of the countries' seabed when resolving how to measure the shelf and establish delimitation lines towards opposite and adjacent coastlines. The court did not opine on the juridical or logical connection between the territorial waters and areas beyond. No alternative bases exist for a claim that this case should bind a decision regarding the Svalbard Treaty's geographic scope. The issue of whether the parties' mainland or islands could be precluded from the parties' own choices regarding continuous zones or shelves beyond their territorial sea was not decided.

The court's obiter dictum offered some relevant and persuasive legal advice. The court addressed the topic of pragmatic, non-principle-based

\footnotetext{
${ }^{105}$ Aegean Sea Continental Shelf, Judgment, ICJ Reports 1978, 3.

106 North Sea Continental Shelf, Judgment, ICJ Reports 1969, 3.

107 ibid, paras 1-7.

108 ibid, paras 96, 51.

109 ibid.

110 ibid, para 100 (emphasis added).
} 
solutions relevant also for the extensions of the treaty to areas beyond the territorial sea of the archipelago. The court warned against a move to 'over-systematize a pragmatic construct the developments of which have occurred within a relatively short space of time'. ${ }^{111}$ Factors such as 'practical convenience and certainty of application', the court held, 'did not suffice', without converting 'what was a method into a rule of law'. Even though the court hesitated to establish normative structures based on relatively scarce data, it did recognise the following single event as defining a new source of the LOS principle:

This régime furnishes an example of a legal theory derived from a particular source that has secured a general following. As the Court has recalled ... it was the Truman Proclamation of 28 September 1945 which was at the origin of the theory, whose special features reflect that origin. ${ }^{112}$

Thus, the coastal state decides - unilaterally - whether to establish an EEZ or a claim involving the shelf, of course with the exception of delimitation line decisions that require bilateral agreements between adjacent and opposite states. Perhaps this general principle of law applies to the possible geographic scope of the Svalbard Treaty.

The Aegean Sea case ${ }^{113}$ is put forward to prove that the Aegean Treaty is valid not only within but also beyond the territorial sea. Due to its concrete application, it is impossible to derive any rules from this case that govern or even shed light on the geographic scope of the treaty.

The Aegean case reveals the subsequent presumption that 'the very idea of the continental shelf was wholly unknown in 1928 when the General Act was concluded and in 1931 when Greece acceded to the Act'. ${ }^{114}$ Greece relied on the Abu Dhabi case to maintain that its reservation did not exclude claims involving the shelf. ${ }^{115}$ The Abu Dhabi arbitrator held that the granting of a mineral oil concession in 1939 was not to be understood as including the continental shelf'. The court in the Aegean case declined, because of an 'essential difference', ${ }^{116}$ to find any analogy.

Further the court stated that issues raising substantive law are different from procedural law. ${ }^{117}$ Compared to the Svalbard conflict, the international law claims for Norway not to discriminate against subjects

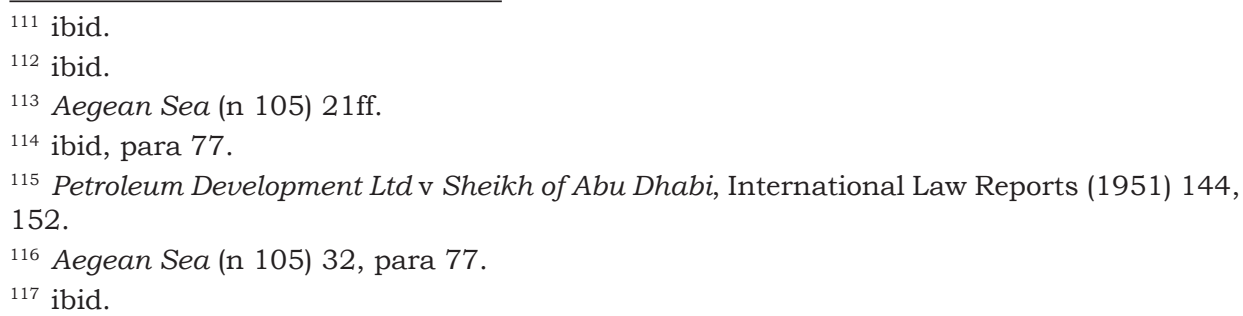


of the Treaty signatories fail to provide any limitation in relation to Norwegian decision-making competences regarding the geographic reach in the Svalbard legislation.

As the exploitation rights in the Abu Dhabi case were not appropriate to resolve the court's jurisdiction in the Aegean case, the court's analysis of its lack of jurisdiction is of limited importance in solving the 'extendedpuzzle' of the Svalbard Treaty. The ICJ's analysis paves the way for reaching this conclusion.

Instead, my idea is that the Abu Dhabi case ${ }^{118}$ is relevant and dispositive. The salient point was who had the right to control the seabed and subsoil of the Persian Gulf adjacent to the coast of Abu Dhabi'?119 In 1939, Sheikh Shakhbut, the Sultan and Ruler of Abu Dhabi, had entered into a contract with the Iraq Petroleum Development Company. Under its terms, the Sheikh 'purported to transfer to Iraq Petroleum the exclusive right to drill for mineral oil within a certain area in Abu Dhabi'. Iraq Petroleum contended that the exclusive rights so granted included the territorial waters and the subsoil of the continental shelf. Abu Dhabi denied this, claiming that the rights were limited to land, and that Abu Dhabi acted legally when leasing the waters and subsoil to another oil company in 1949.

In deciding the dispute, the arbitrator framed the issues as follows. First, 'at the time of the Agreement did [the Sheikh] own ...the right to win mineral oil from the subsoil of any, and, if so, what sub-marine area lying outside territorial waters?' Second, if this answer is in the positive, 'was the effect of the Agreement to transfer such original or acquired rights to the Claimant Company?'120 'Directed as I apprehend I am', the judge stated, 'to apply a simple and broad jurisprudence to the construction of this contract, it seems to me that it would be a most artificial refinement to read back into the contract the implication of a doctrine [on Continental Shelf] not mooted till seven years later'. ${ }^{121}$

Hence, ex post facto legal events cannot re-define the legal position taken by contracting parties to an agreement signed many years before disputes arise thereunder. Examining the geographic scope of the Svalbard Treaty, general principles of law apply. The stepping stone for this conclusion is the fact that critics' ratione terrae claims are utterly unsupported by the Treaty itself. This means that we must solve the issue by looking to LOSC and customary and general principles of law.

\footnotetext{
118 Reprinted in International and Comparative Law Quarterly (April 1952) 247.

${ }^{119}$ Edwin J Cosford Jr, 'The Continental Shelf and the Abu Dhabi Award' (1953) 1 McGill Law Journal 109.

${ }^{120}$ International and Comparative Law Quarterly 247 (1952) 248.

121 ibid 253.
} 


\subsection{Comparable developments: US treaties with natives}

A possible comparison relevant for the critics' position of Norway in the Svalbard Treaty's 'long-arm-reach puzzle' is the United States' accession treaties with Indian tribes and the terms on which new states like Texas and Alaska were admitted to the Union in the 1800s. The Indian tribes $^{122}$ and inhabitants of Alaska, Texas, ${ }^{123}$ Hawaii ${ }^{124}$ and others kept their states' rights after joining the Union.

Inhabitants who benefited from exclusive territorial fishing rights determined under the terms of the treaties or other legal documents by which the states joined the Union gain no extended 'coastal rights' beyond the original belt, ${ }^{125}$ pursuant to LOSC development. The United States possess these rights. It is undisputed that evolving rights under LOSC accommodate the federal state, not individual 'component' states.

The US solution parallels the Norway case. The Svalbard Treaty privileges within the territorial sea benefit the nationals of the parties. The terms of the Treaty set them forth. Change to the LOS, on the other hand, offers inhabitants no claim beyond the territorial sea. It is clear that those rights benefit the USA and not the citizens of the national states.

\subsection{Subsequent development: the significance of EEA provisions}

Subsequent development 'regarding the interpretation of the treaty or the application of its provisions' (article 31.3 VCLT) is a relevant interpretative factor. What is its contribution to unraveling the Svalbard Treaty puzzle?

As stated by the Vienna Convention, the parties' subsequent express or tacit dispositions may contribute to the interpretation of a treaty. One such occurrence is the Norwegian accession to the EEA agreement of 2 May 1992. What solutions to the ratione terrae puzzle derive from EEA accession?

Article 126 EEA codifies the treaty's jurisdictione ratione terrae: 'The Agreement shall apply to ... the territories of Iceland, the Principality of Liechtenstein and the Kingdom of Norway'. What do 'the territories of ... Norway' signify?

\footnotetext{
${ }^{122}$ See Treaty with the Tribes of Middle Oregon, 1855. 25 June 1855 (12 Stats 963) Ratified 8 March 1859 - Proclaimed 18 April 1859.

${ }^{123}$ A Treaty of Annexation, concluded between the United States of America and the Republic of Texas 12 April 1844.

${ }^{124}$ Treaty of Annexation between the Republic of Hawaii and the United States of America (1898).

${ }^{125}$ For a theoretical approach, see Gary Lawson, 'Territorial Governments and the Limits of Formalism' (1990) 78 California Law Review 853, 853.
} 
Svalbard is part of the Kingdom of Norway and incorporates under the EØS-concept 'territories of ... the Kingdom of Norway'. However, Norway may exempt the territory of Svalbard from the treaty's application. EEA Protocol 40 states:

1. When ratifying the EEA Agreement, the Kingdom of Norway shall have the right to exempt the territory of Svalbard from the application of the Agreement.

2. If the Kingdom of Norway avails itself of this right, existing agreements applicable to Svalbard, i.a. the Convention establishing the European Free Trade Association, the Free Trade Agreement between the European Economic Community and the Kingdom of Norway ... shall continue to apply to the territory of Svalbard.

What solutions to the ratione terrae puzzle derive from accession to the EEA? First of all, the competence to decide whether the EEA applies to 'the territory of Svalbard' belongs to Norway. This includes, first, the unilateral use of this exemption and, second, the ultimate right to define what is the geographic reach of the concept of 'territory'. Thus, the possible 'long arm reach' of the Svalbard Treaty is unilaterally to be decided by Norway. If neither the signatories of the EEA nor the Svalbard Treaty object, the Norway position is tacitly acknowledged and thus de facto recognised.

Secondly, the Norwegian act of EEA accession of 27 November 1992 No 109, § 6 states: 'This act does not apply to Svalbard'. Accordingly, Norway exempted 'the territory of Svalbard'. This provision does not, however, specify whether 'Svalbard' relates to the areas within the Svalbard Box only, or relates to areas beyond the Box or at least beyond the territorial sea (Act on Norway's Territorial Waters and Contiguous Zone of 27 June 2003 No 57 § 2). Accordingly, Norway unilaterally increased the geographic reach of the Svalbard Treaty from 4 nautical miles to 12 nautical miles (in 2003). Neither signatories nor parties to the treaty objected to the Norwegian decision.

Does the EEA agreement apply to the FPZ and continental shelf beyond the Svalbard territorial waters? The answer derives from the 1982 LOSC Part XI, article 76: the 'natural prolongation of its land territory', ie the physical continental shelf of Norway which embraces the entire plateau of Norway's mainland, stretching out north - including Svalbard and continuing up to the margin of the Arctic Ocean - the deep seabed area. Since the UN Continental Shelf Commission recognised the Norwegian claim, ${ }^{126}$ the Norwegian proposed outer line for the national continental shelf is de facto and de jure valid.

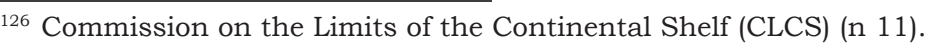


How to understand the concept of 'territories of ... Norway' as codified in article 126(1) EEA: 'The Agreement shall apply ... to the territories of Iceland, the Principality of Liechtenstein and the Kingdom of Norway'? The original Norwegian position is that 'territory' relates to the entire land base as well as the territorial sea. The EEA does not include areas beyond the territorial sea such as the exclusive economic zone and the continental shelf. Norway, however, failed in domestic courts to gain support for this position. The justification in the Leinebris case related to Norway's requirements for the nationality of a crew which contradicted the basic principle of free movement of persons (article 28 EEA) was that:

Even though the EEA, article 126 paragraph 1, relates to the application of the agreement in the actual countries' territories, the High Court finds it a too formalistic interpretation to claim that areas beyond the territorial sea are excluded from the EEA agreement ... In respect of the geographic reach of the EEA agreement, the High Court is supportive of the ESA [EFTA Surveillance Agency] conclusive remark in the opening letter stating that sailors' conditions of employment should apply also within the Exclusive Economic Zone [EEZ] of Norway due to the fact that sailors' working conditions on board are sufficiently closely attached to the EEA territory. ${ }^{127}$

Since Svalbard - within the territorial sea - is exempt from the EEA agreement, this means that the entire continental shelf, the EEZ of mainland Norway, the Jan Mayen Fisheries Zone, and the FPZ of Svalbard are part of the EEA agreement, as resulting from the 'Leinebris case'.

No EU objections arose either to the extension of the Svalbard territorial sea to 12 nautical miles, the High Court 2006 decision or the UN's continental shelf decision of 2009. Consequently, the court-endorsed ESA position is supportive of the Norway position on the limited geographic reach of the Svalbard Treaty.

\section{Concluding remarks}

'The Government will seek international acceptance of Norwegian views on Svalbard, fishing zones, oil and gas extraction and sound environmental management'. ${ }^{128}$

The Treaty irrevocably furnished Norway with exclusive sovereignty over Svalbard. It includes no redemption, cancellation or revision procedure.

\footnotetext{
${ }_{127}$ Frostating High Court decision of 21 September 2006 (Leinebris case) LF-2006-24118, 9. The decision was appealed to the Norway Supreme Court. However, the Norwegian government withdraw its appeal one week before the court negotiations were scheduled to start.

128 The Office of the Prime Minister, 2007 Report; Soria Moria Declaration <www.regjeringen.no/en/dep/smk/documents/Reports-and-action-plans/rapporter/2005/The-SoriaMoria-Declaration-on-Internati.html?id=438515> accessed 29 May 2013.
} 
Thus, subsequent 'creeping' jurisdiction due to new developments cannot creep up on Norway. And neither can they creep up concerning Svalbard. Whether advances in LOSC involve use of the sea, whether the developments are good or bad, whether they might otherwise benefit or burden Norway - if they apply - is irrelevant. They do not.

Norway's sovereignty is nothing special, in the sense that the right to decide is, as in all other nations, a residual right, and not a 'special' kind of sovereignty. This right belongs to the sovereign, regardless of how original acquisition occurred. The contracting parties cannot repeal Norwegian provisions governing life on Svalbard.

Svalbard is part of the Kingdom of Norway, just as Hawaii is part of the US. Norway enjoys jurisdiction in Svalbard, as does the US in Hawaii. The several states and Indian tribes of the United States, some of which enjoy on behalf of their inhabitants special rights of harvest within the territorial sea according to the accession treaties, failed to benefit from the 1970s development of the LOS.

The Treaty has neither a time limit nor any withdrawal clause. Even though contracting states parties may withdraw from the Treaty, this move cannot reverse the sovereignty of Norway. It contains no clause of reversal. If such a 'volte-face' should take place, Norway, as one of the states parties, must agree.

Some critics of Norway confuse economic rights with jurisdictional rights, ie the right to harvest with the jurisdictions of the sovereign state. This is a common mistake, after all. The right to decide if and how to govern, ie to conduct legislative, surveillance and hold enforcement power, is different from the right to trade, fish and harvest. The equal rights stipulation which does not include the right to decide how to govern belongs exclusively to Norway. Sovereignty is 'full and absolute'.

Another explanation for the interpretative stances adopted by critics is the 'logical' and 'natural' deduction from what might have been the plenipotentiaries' common intention if future development under the Law of the Sea were known to the representatives. In support, they allege that the 1920 Treaty contains evolutionary concepts, directing dynamic interpretation. However, neither the representatives' intentions nor the treaty text itself champions this position.

In accordance with the ordinary meaning of the terms of the Treaty, future economic activities and gains within its geographic scope are protected, but the Treaty cannot be interpreted to confer these rights also in contiguous marine areas outside its geographic scope. It is beyond dispute that the Treaty protected the Member States' going concern, future economic activity and gains. According to the Treaty, these rights are protected, but only within the geographic scope of the Treaty. Hence, deep seabed mining, oil drilling or high seas fishing do not constitute protected 'equal rights' granted to the parties of the Svalbard Treaty. 